\title{
Editorial Great is truth
}

EOGRAPHICAL remoteness, small populations and vast sea dis-

Tances between nations are all factors which go to ensuring that the islands of the Pacific remain relatively unfamiliar territory to many in the international community. That a region so wealthy in languages, cultures and social traditions could also be a place of coups and tensions and where media freedoms are often trampled upon, is also little known to many casual observers.

An opportunity for independent Pacific media voices to be heard and for press freedom activists to express concerns on the international stage came to the fore when the UNESCO Director-General agreed to the University of Queensland's bid to host, for the first time in the Pacific, the annual UNESCO World Press Freedom Day conference (2-3 May 2010). While global in nature, the conference addressed Pacific issues as a priority.

As the more than 300 delegates from more than 40 countries arrived in Brisbane for the event, they would have noticed the wording 'Great is Truth, and Mighty Above All Things' etched into the sandstone façade over the main portal at the university. The message could not have been more appropriate for a conference with the theme Freedom of Information: The Right to Know.

Although the conference included sessions specifically devoted to Pacific press freedom issues, it more importantly provided a platform for journalists and media professionals from the region to gather in special pre and postconference workshops to discuss concerns and fears about repressive regimes, restrictive Government legal practices and the need for improved skills-based training, especially in FOI fields. Women journalists came together for a WAVE meeting, while the Pacific Freedom Forum (PFF) also gained strength through networking among interested parties. Sadly, due to internal divisions and disagreements, the region's once pre-eminent media organisation, the Pacific Islands News Association (PINA), played no part in the proceedings.

This 'UNESCO WPFD: Media Freedom in Oceania' themed edition of Pacific Journalism Review brings into focus some of the outcomes of the global World Press Freedom Day conference.

Lisa Williams-Lahari launches into the subject with a strong commentary which gives us, as she puts it, a 'funky taste of Pacific media freedom soup'. Ensuring that we feel more embedded in the region, she goes on to place the 
role of media in a cultural context through an interesting consideration of the traditional toki, or adze.

The 'fiercely independent' Cook Islands News is profiled by its editor, John Woods, who also recalls the way in which the country pioneered Freedom of Information legislation in the region. However, he goes on to lament the fact that subverting application of the whole FOI process seems to have become a national sport for politicians.

At the time of the Brisbane conference, Sophie Foster was assistant editor of The Fiji Times. Since then, the newspaper has fallen victim to a draconian media law introduced by the military regime to curb foreign ownership of the press. Rupert Murdoch's News Ltd has been forced to divest itself of its flagship newspaper, the once proud Fiji Times, to a locally-based buyer-the Motibhai Group. Fortunately, we have Sophie's recollections of life under censorship at the Fiji Times to remind us of how journalists were denied the opportunity to go about their work.

A Papua New Guinea perspective to threats to media freedom is provided in a commentary by Port Moresby based Susuve Laumea, interim Chair of the Pacific Freedom Forum. PFF is an online forum of journalists, media professionals, academics and other parties concerned about the erosion of the rights espoused by Article 19 of the Universal Declaration of Human Rights. He takes the opportunity to revisit what he rightly calls 'the sacred values of freedom of information and freedom to express, analyse and disseminate information'.

In an illuminating piece on the trials and tribulations of establishing and owning a newspaper in the Pacific, The Samoa Observer's Savea Sano Malifa, starts with its historical roots in a 'cookhouse in a village near Apia'. A prominent politician of the time, later to become the country's Head of State, begrudgingly gave support to its establishment but that did not save the paper from later difficulties, such as destruction of its offices and printing press by fire. As this edition was going to press Savea was honoured by the International Press Institute as one of 60 global 'media freedom heroes'.

Vanuatu governments are not used to being held accountable. MarieNoelle Ferrieux Patterson makes this assertion in her erudite and illuminating commentary on the Vanuatu experienceof Freedom of Information. As president of Transparency Vanuatu, Marie-Noelle's experiences as the country's first Ombudsman also give an insight into how 'big men' in a Pacific society often feel threatened by FOI and believe they are not accountable. 


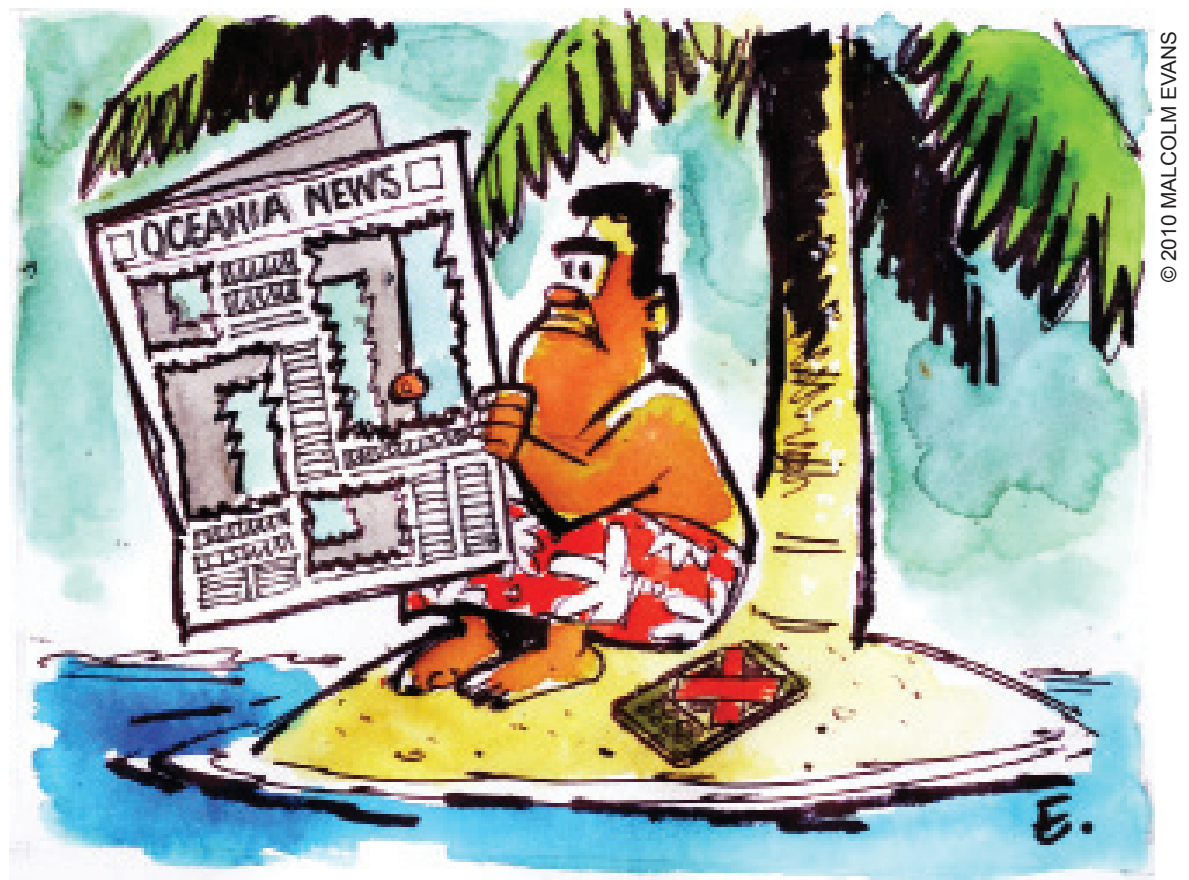

From a professional background which includes a senior broadcast management role in Fiji, Vanuatu-based Frances Herman tackles the vexed question of the digital divide and the way in which remote Pacific communities can engage with new technologies. Clearly, there is a long way to go.

In most countries of the world, the role of Chief Ombudsman would probably involve the incumbent in a seemingly endless round of investigations into minor bureaucratic bungles and government department administrative errors. Not so in Papua New Guinea, where Chronox Manek is Chief Ombudsman. He is not only a Pacific hero, but a global warrior on the frontlines in the fight against corruption and poor governance. His work has been so effective that he was savagely attacked and badly wounded in Port Moresby while going about the performance of his duties. Chronox Manek came to the WPFD 2010 conference from medical treatment in Melbourne. His chapter on Freedom of Information - Challenges and the Way Forward is a must read.

Introducing the research articles, an erudite, academic overview of media development in Tonga takes us from the 1800 s to the present day. Doctoral 
candidate and former Tonga radio/TV news editor, Sione Fatanitavake Vikilani, shows us that, as early as 1882 , the media had their first confrontation with the authorities. Has anything changed in the past 100 years? Let the chapter on Media Freedom and State Control in Tonga be your guide.

How close is Fiji to adopting the 'guided journalism' style common in Singapore and Malaysia? Reggie R. Dutt studies the Media Industry Development Decree in Fiji and compares it with a similar Act promulgated in Singapore in 2003. Harsh fines, jail terms, wide powers to search, seize and censor. But does one size fit all? Will it work in Fiji? The author evaluates the situation in 'Fiji media decree: A push towards collaborative journalism'.

David Robie of AUT University's Pacific Media Centre in New Zealand takes a broader brush to the subject of freedom of the press by providing perspectives on campus-based media models in the Pacific. This was the subject of his invited UQ School of Journalism and Communication World Press Freedom Day Lecture presented as a pre-conference event. The theme of this PJR edition is rounded off by Mosmi Bhim and Shailendra Singh with chapters on the effects of press censorship in Fiji.

Two additional non-themed articles bring perspectives to differing subjects. Trevor Cullen and Ruth Callaghan look at how the press has reported HIV incidences in Papua New Guinea, while Babak Bahador and Serene Tng takes the Mumbai terrorist attacks of 2008 as the base for an analysis of the way in which citizens caught up in conflict can play a role in framing the reporting of the events.

My sincere thanks go to all who have contributed to this edition. Special thanks to my co-editors, Marsali Mackinnon, of the University of Queensland and Associate Professor David Robie of AUT University in Auckland. We are also grateful to the UNESCO Office for the Pacific States in Apia for financial support for the publication of this edition.

\author{
Associate Professor Martin Hadlow \\ Convenor, WPFD 2010 \\ The University of Queensland \\ St Lucia, Brisbane, Australia \\ www.wpfd2010.org
}




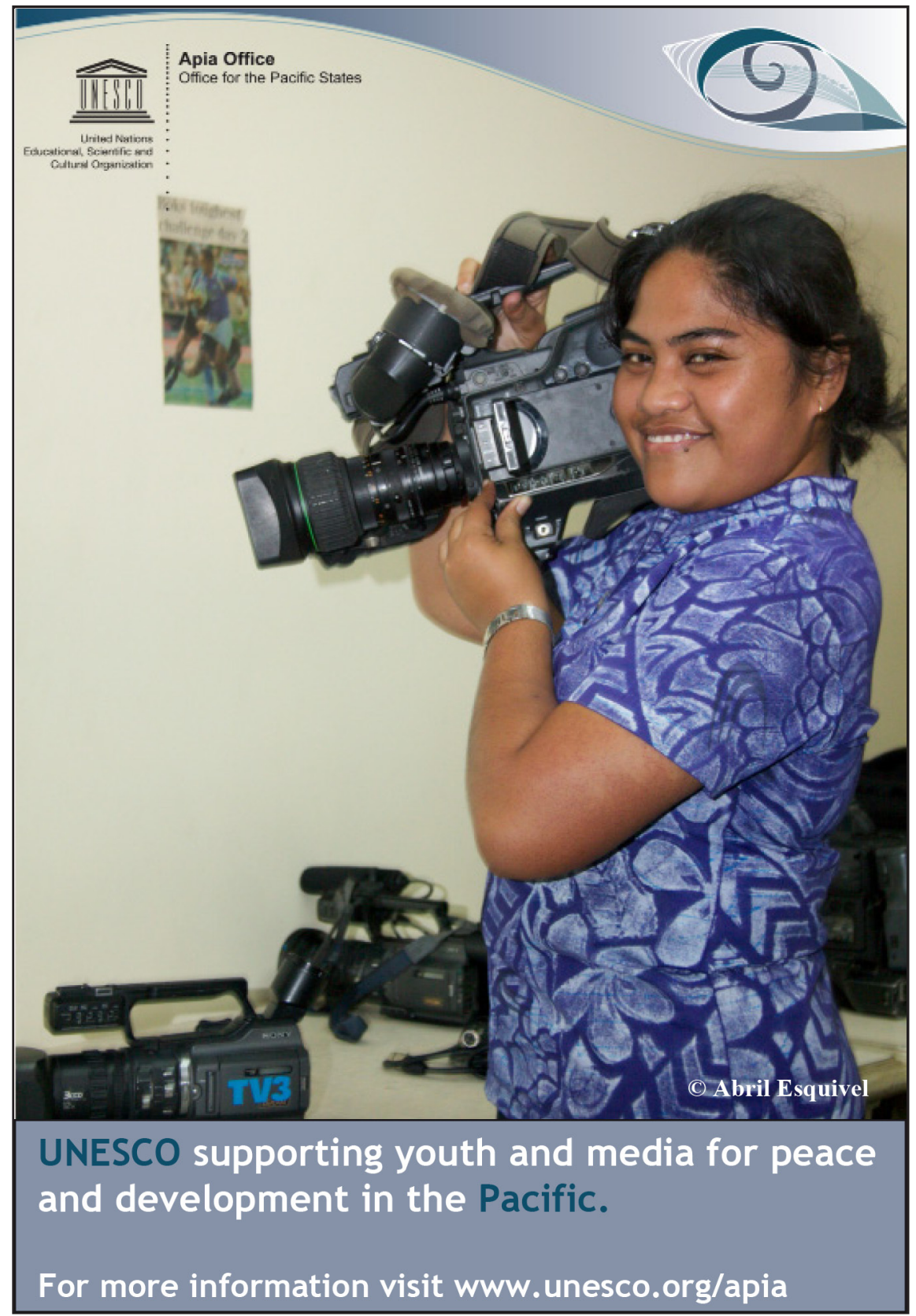

PACIFIC JOURNALISM REVIEW 16 (2) 20109 